\title{
Miejsca węzlowe jako elementy krystalizujące obszary mieszkaniowe powstałe w XX i XXI wieku
}

\section{Grażyna Schneider-Skalska}

\author{
Katedra Ksztaltowania Środowiska Mieszkaniowego, Wydziat Architektury, Politechnika Krakowska, \\ e-mail: gsskalska@.interia.pl; gschneid@pk.edu.pl
}

Streszczenie: Wzrost ilości ludności miejskiej to wzrost ilości mieszkań, powiększanie terenów zajętych przez zespoły mieszkaniowe, to również wyraźnie widoczne zjawisko chaosu przestrzennego, braku kompozycji urbanistycznej oraz form i miejsc krystalizujących przestrzeń. Diagnozy opracowane dla środowiska mieszkaniowego mówią o takich cechach nowo kreowanych przestrzeni osiedlowych jak: brak ciągłości układów komunikacyjnych, nieoptymalne powiązania terenów czy nieoptymalne lokalizowanie usług publicznych i terenów zielonych. Obszary mieszkaniowe w strukturze miasta dominują zarówno pod względem zajmowanego obszaru jak i wielkości substancji zabudowy. Stąd ich rozmieszczenie nie powinno być przypadkowe, a przynależny im program usługowy nie może być szczątkowy i rozmieszczony chaotycznie. Miejsca węzłowe jako jeden z elementów krystalizujących przestrzeń miasta wydają się być szczególnie pożądane w niekształtnych, nowych obszarach mieszkaniowych, powstałych po 1989. Problem wydaje się być szerszy, bo w badaniach wskazywany jest też brak miejsc krystalizujących w dużych osiedlach wielorodzinnych z lat 60. i 70. Myślenie o systemie miejsc węzłowych prowadzi wprost do powrotu do modeli w planowaniu urbanistycznym. Miejsca węzłowe tworzące sieć to wyznaczniki funkcjonalno-przestrzenne, które mogą pomóc w kontynuacji i uczytelnieniu struktury miejskiej w bezładnie rozwijających się obszarach. Mogą wyznaczać skalę i miejsce w hierarchii, wprowadzać wyróżniający wyraz architektoniczny pozostawiając dużo swobody w kształtowaniu przestrzeni miedzy węzłami.

Słowa kluczowe: obszary mieszkaniowe, miejsca węzłowe, modele urbanistyczne.

\section{Wprowadzenie}

Jak wykazują prognozy liczba miejskiej ludności w skali świata ale i w skali Polski będzie się zwiększać, niezależnie od zróżnicowanego tempa przyrostu naturalnego, a także zauważalnego szczególnie w mniejszych miastach ubytku liczby mieszkańców. Wzrost ilości ludności miejskiej to również potęgujące się skomplikowanie problemów przestrzennych, programowych i społecznych oraz wzrost negatywnych zjawisk i zagrożeń dla jakości środowiska miejskiego. To wyraźnie widoczne zjawisko chaosu przestrzennego, braku kompozycji urbanistycznej oraz form i miejsc krystalizujących przestrzeń. To najczęściej dezintegracja i fragmentacja przestrzeni w obszarach poza śródmieściem, brak przestrzeni publicznych dla miejsc spotkań i integracji, zjawisko separacji społecznej skutkującej gettoizacją. Ocen jakości polskiego środowiska miejskiego podejmowało się szereg gremiów, żeby wymienić tylko takie opracowania jak „Polska Polityka Architektoniczna” [1], czy „Przestrzeń Życia Polaków - diagnozy i rekomendacje"[2]. Diagnozy opracowane dla środowiska mieszkaniowego 
mówią o takich cechach nowo kreowanych przestrzeni osiedlowych jak: brak ciągłości układów komunikacyjnych, nieoptymalne powiązania terenów czy nieoptymalne lokalizowanie usług publicznych i terenów zielonych, brak czytelności i sieci przestrzeni publicznych. W większości diagnoz pojawia się rok 1989, jako ten, po którym nastąpiło zintensyfikowanie negatywnych zjawisk. Problem wydaje się jednak być szerszy, bo w badaniach wskazywany jest też brak miejsc krystalizujących w dużych osiedlach wielorodzinnych z lat 60. i 70.

\section{Budowanie struktury mieszkaniowej}

Miejsca węzłowe to tylko jeden z elementów krystalizujących przestrzeń miasta, wymieniony już przez K. Wejcherta [3] i K.Lyncha [4], jednak również pozostałe: ścieżki, krawędzie, rejony czy punkty charakterystyczne są jednakowo ważne i dopiero one wszystkie razem, traktowane łącznie, pozwalają na uporządkowanie i zapewnienie czytelności obszarów zurbanizowanych, w tym obszarów mieszkaniowych. Obszary mieszkaniowe w strukturze miasta dominują. Zarówno pod względem zajmowanego obszaru jak i wielkości substancji zabudowy. Stąd ich rozmieszczenie nie powinno być przypadkowe, a przynależny im program usługowy nie może być szczątkowy i rozmieszczony chaotycznie. Fizyczna postać funkcji mieszkaniowej w miastach to struktury niejednorodne, zależne od strefy miasta, w której się znajdują. Przedmiotem rozważań w tym tekście są obszary o dominującej funkcji mieszkaniowej - duże osiedla wielorodzinne i obszary pokaźne terytorialnie, zabudowane małymi, wielorodzinnymi zespołami deweloperskimi. Oba te typy obszarów występują poza strefą śródmiejską, a poprzedzają strefę przedmieść i dominującej zabudowy jednorodzinnej, rozproszonej.

W roku 2015 roku Zespół Instytutu Projektowania Urbanistycznego Wydziału Architektury Politechniki Krakowskiej przeprowadził badania w ramach projektu „Pilotażowy Program Rehabilitacji osiedli Ugorek i Olsza II w Krakowie”, które to badania miały wskazać wady i zalety tych osiedli, powstałych w latach siedemdziesiątych [5]. W badaniach szukano odpowiedzi na trzy podstawowe pytania, jakie należy sobie zadać mówiąc o współcześnie zamieszkiwanych osiedlach: czy osiedle ,żyje”, czy jest wygodne i czy stwarza zdrowe warunki życia. Wyniki badań nie były jednoznaczne. Większość mieszkańców była zadowolona z miejsca zamieszkania, jednak w trakcie spotkań i szerszych dyskusji wyartykułowano również wady i niedogodności. To przede wszystkim brak charakterystycznych wyznaczników funkcjonalno-przestrzennych, brak węzłów, które skupiałyby funkcje i mieszkańców, dostarczały cech wyróżniających, z którymi mieszkańcy mogliby się utożsamiać.

Jeszcze wyraźniej zjawisko braku miejsc węzłowych występuje w dużych obszarach pokrytych małymi, deweloperskimi zespołami mieszkaniowymi. Przykład obszaru Ruczaj w Krakowie jest dla tego zjawiska przykładem „klinicznym”. Badania nad tym obszarem zespół Katedry Kształtowania Środowiskowego Mieszkaniowego przeprowadził w roku 2015/16 w ramach studiów podyplomowych prowadzonych we współpracy z Urzędem Miasta Krakowa [6]. Nowe, duże skupisko budynków, ulic, uliczek, ogrodzeń stało się nawet dla stałych mieszkańców labiryntem trudnym do przebycia. Brak miejsc węzłowych i punktów charakterystycznych, brak odniesień do sąsiednich terenów i powiązań z nimi powoduje, że nie jest to ani czytelny fragment struktury miasta ani samodzielny organizm skupiony wokół miejsca węzłowego. Sąsiedztwo atrakcyjnego kampusu UJ nie wywołało pozytywnych zjawisk. Wręcz przeciwnie. Kampus oddzielony od obszarów mieszkaniowych ruchliwą ulicą i ekranami akustycznymi, jest niedostępny, a nawet niewidoczny dla mieszkańców osiedli. Potencjał, jaki tkwił w tym obszarze nie został wykorzystany, a jego odkrycie wymagać będzie wielu zabiegów i działań przestrzennych. 


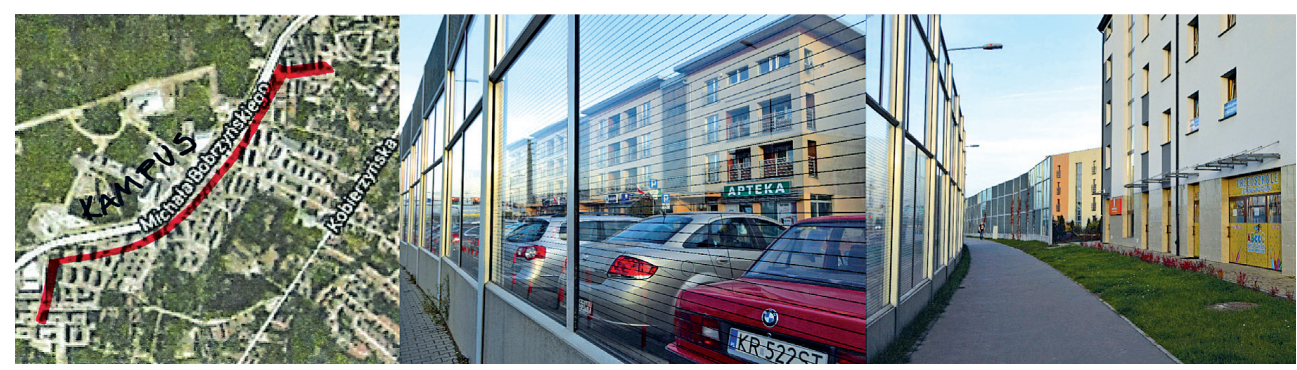

Il. 1. Osiedle Ruczaj w Krakowie: czarna linia wyznacza trudna do przekroczenia granicę/barierę pomiędzy obszarem mieszkaniowym i Kampusem UJ (opr. autorki), a Il. 2 i 3 pokazują negatywne skutki zagospodarowania terenu, nieuwzględniającego przestrzennych relacji liniowych i punktowych (fot. Autorki)

Pojawia się pytanie czy mieszkańcy rzeczywiście oczekują czytelności, miejsc węzłowych, hierarchizacji przestrzeni. Dają się bowiem zauważyć systematyczne zmiany w odbiorze przestrzeni przez użytkowników spowodowane inwazją środków komunikacji wirtualnej. Psychologowie zauważają zarówno pozytywne jak i negatywne skutki przenoszenia się do rzeczywistości wirtualnej i zrywania z przynależną ludziom umiejętnością obserwacji, analizowania i wnioskowania.

Jak pisze A. Palej ,,Nowy świat z wieloma nowościami, podbudowywanymi przez zaawansowane technologie przynosi moc ogromnych możliwości. Infrastruktura telematyczna staje się obecna we wszystkich skalach, sektorach i funkcjach, co sprawia, że wszelkie aspekty życia miejskiego podporządkowują się w coraz większym stopniu logice Sieci oraz strukturom przepływu kapitału, informacji, technologii i symboli. Pojawiają się nowe modele przestrzeni z bogatą ofertą usługową, poszerzającym się repertuarem wartości społecznych oraz wirtualnym wymiarem człowieka, budynku i miasta. Świat zdaje się też poruszać coraz szybciej - skracają się i stają bardziej wyrywkowe relacje człowieka z miejscami, przedmiotami i innymi ludźmi." [7]

Jednocześnie B. Dobroczyński [8] pisze, iż mamy do czynienia z cywilizacją zniecierpliwienia. Ma na myśli coraz większe przyzwyczajenie do szybkości otrzymywania informacji i nie tylko. Stąd już tylko krok do stwierdzenia, że poszukiwanie komfortu użytkowania oznacza bliskość programu użytkowego, która daje nam wszystko czego oczekujemy w jednym miejscu i w krótkim czasie. Ta bliskość i skupienie funkcji i form pozwala na szybkie zaspokojenie potrzeb, a równocześnie staje się miejscem ważnym, zapamiętywanym i w miarę stałym, bo wg A. Tofflera: „W nowym wirującym świecie nie może się sprawdzić żadna życiowa strategia poza strategią elastyczności, a człowiek potrzebuje choćby minimum psychicznej stabilizacji" [9].

Wydaje się, że planowanie, kształtowanie, ulepszanie istniejących i tworzenie nowych węzlów w nowopowstających obszarach jest jakąś próbą odpowiedzi na te sprzeczne, wydawałoby się, oczekiwania.

Można powiedzieć, że planowanie jako konieczny składnik rozwoju odzyskuje swoją rangę w kształtowaniu obszarów mieszkaniowych, w wyniku diagnoz, jakie opracowano między innymi dla tych terenów. W opracowaniu Przestrzeń Życia Polaków napisano między innymi: „Planowanie przestrzenne...ma charakter formalny i niekonstruktywny. ...Brakuje pracy na modelach przestrzennych przy kształtowaniu istotnych elementów przestrzeni miejskiej. Brakuje planów zagospodarowania przestrzeni publicznych, a liczba realizacji 
gminnych mających na celu poprawę jakości przestrzeni miasta jest niewielka. Poprawę poziomu życia Polaków oraz ograniczenie zjawiska wykluczenia społecznego można uzyskać przede wszystkim przez większą dostępność ośrodków miejskich stanowiących węzły aktywności gospodarczej i miejsca świadczenia usług różnego rzędu [10].

W najważniejszych deklaracjach programowych - od Karty Nowej Urbanistyki poczynając, a na Polskiej Polityce Architektonicznej kończąc - ich sygnatariusze podkreślają, że sztuka budowania miast powinna obejmować również umiejętność tworzenia społeczności lokalnych, eksponowania lokalnych tradycji osadniczych, dziedzictwa kultury i historii. To zaś zakłada znaczący udział przyszłych mieszkańców w procesie projektowania miejsc wspólnych - przyjaznych, zwartych, dostępnych dla pieszych, dzieci i osób starszych, z dobrze rozwiniętą komunikacją publiczną. Jak piszą E. Czyżewska i A. Czyżewski, pojęcie „miejsca wspólnego" nie ma definicji ustawowej, prezentują więc swoją autorską, która mówi: „Miejsce wspólne jest fragmentem przestrzeni publicznej miasta, wsi lub innej jednostki osadniczej, w którym ujawnia się ważny splot interesów publicznych, praktyk społecznych i oczekiwań mieszkańców. Architekturę miejsca wspólnego określa projekt urbanistyczny, uzupełniający na poziomie szczegółowych rozwiązań przestrzennych i funkcjonalnych ogólne zapisy lub brak zapisów w miejscowym planie zagospodarowania przestrzennego. Dokumentacja powykonawcza w części przypisującej miejscu wspólnemu niezbywalne właściwości formalne (architektoniczne, urbanistyczne, wizualne), staje się w wyniku uchwały samorządu elementem prawa miejscowego. Służy ona ochronie ładu przestrzennego, także w zakresie artykulacji granic nieruchomości, nasadzeń zieleni oraz ochrony spójności i ładu wizualnego w przestrzeni publicznej, nie wyłączając z zakresu właściwości chronionych także przestrzeni wizualnej posesji prywatnych tworzących wraz z miejscem wspólnym jedno wnętrze urbanistyczne.” [11].

Niewątpliwie powyższa definicja określa cechy miejsca węzłowego w obszarach mieszkaniowych. Miejsce węzłowe, o czym już była mowa, powinno być elementem sieci, a sieć powinna powstawać $\mathrm{w}$ wyniku planowania i przemodelowywania uwzględniającego czasem nieprzewidywalne zjawiska i zachowania.
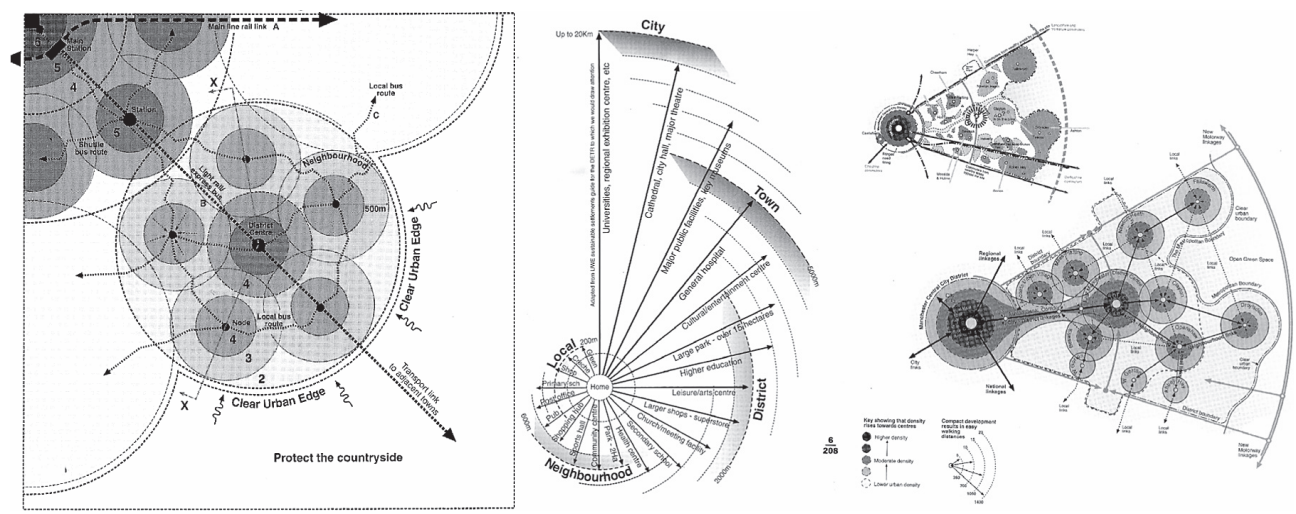

Il. 4, 5, 6. Budowa koncepcji rozwoju wschodniego Manchesteru, autorstwa zespołów: Richard Rogers Partnership i Andrew Wright Associates, polegała na wykorzystaniu modelu teoretycznego (il. 4), wymaganych promieni dostępności (il. 5), zbadaniu potencjału poszczególnych jednostek i sporządzeniu sieci punktów węzłowych o różnym znaczeniu opartej na modelach dostępności i komplementarności programu (il. 6); ilustracje w:[12] 
Myślenie o systemie miejsc węzłowych prowadzi wprost do powrotu do modeli w planowaniu urbanistycznym. Modeli, które w Polsce wydają się odzyskiwać należne im miejsce w procesie optymalizacji rozwiązań. Teoretyczny model jest wciąż aktualnym i niezbędnym narzędziem dla prawidłowego planowania rozwoju miasta. To narzędzie przydatne i stosowane w krajach europejskich, dla których samo słowo planowanie nie ma skojarzeń pejoratywnych. Przydatność tego narzędzia w planowaniu rozwoju przestrzennego pokazuje współczesny przykład modeli rozwoju Manchesteru, wykonanych przez Richarda Rogersa z zespołem [12], a analiza modeli jednostek, osiedli i dzielnic mieszkaniowych konstruowanych już w latach 70. XX. wieku w zespole W. Cęckiewicza przypomina o miejscu polskiej teorii urbanistyki w skali Europy w zakresie modelowania i kształtowania sieci osadniczej [13].
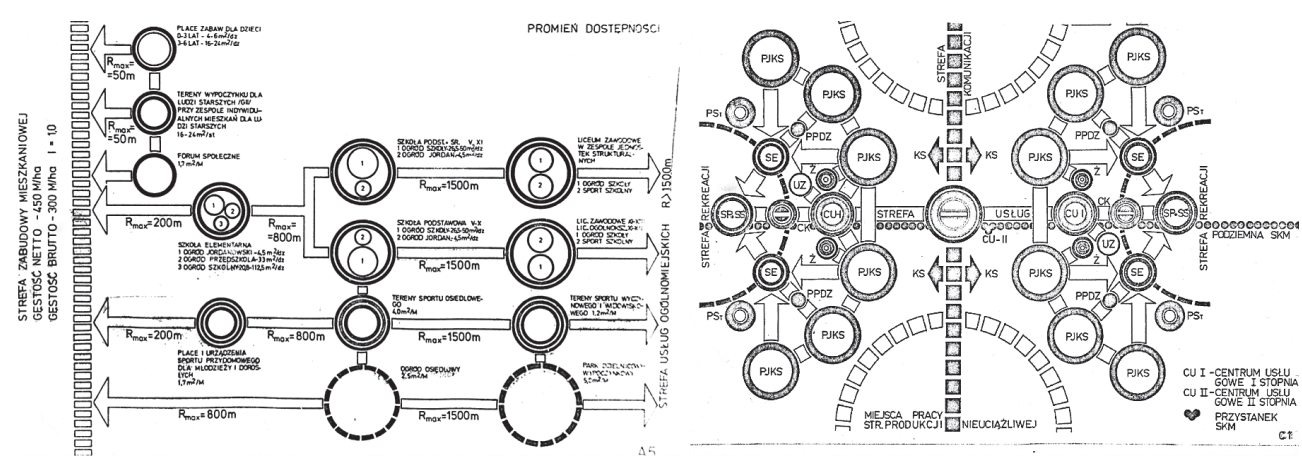

Il. 7 i 8 . Modele programowo-przestrzenne w planowaniu obszarów miasta, ze szczególnym uwzględnieniem roli obszarów mieszkaniowych stosował W. Cęckiewicz z zespołem, w pracach Instytutu Urbanistyki i Planowania Przestrzennego Wydziału Architektury Politechniki Krakowskiej w latach 70. dwudziestego wieku. Promień dostępności do usług różnego rzędu (il. 7) determinował rozmieszczenie miejsc węzłowych (il. 8). [ilustracje w: 13]

\section{Podsumowanie i przykłady jako wnioski}

Miejsca węzłowe tworzące sieć to wyznaczniki funkcjonalno-przestrzenne, które powinny nawiązywać do tradycyjnej struktury miasta i podkreślać już istniejące czy wynikające z tradycji ważne punkty. Mogą też pomóc w kontynuacji i uczytelnieniu struktury miejskiej w bezładnie rozwijających się obszarach, nadając im miejsce w hierarchii, wyznaczając ich skalę i nadając wyróżniający wyraz architektoniczny ale też pozostawiając dużo swobody w kształtowaniu przestrzeni miedzy węzłami. Wydaje się też, że atrakcyjne miejsce węzłowe, wyróżniające się architekturą odpowiada potrzebom współczesności, bo jak pisze przywoływany już B. Dobroczyński [8] współczesne społeczeństwo nazywane jest społeczeństwem spektaklu, (określenie wprowadzone przez francuskiego filozofa Guya Deborda) Miejsce węzłowe dostarcza „sceny” i widowni realnej, niezależnie od funkcjonowania wirtualnej. Planowanie lokalizacji nowych węzłów czy wzmocnienia istniejących musi uwzględniać hierarchię węzłów i współczesne rozumienie czasu. „Coraz częściej na pytania zadawane o odległość padają odpowiedzi, które podawane są w jednostkach czasu. Dobre autostrady i komfortowe samochody sprawiają, iż 45. minutowy dojazd do pracy i 15. minutowa droga do wybranego centrum usługowego nie są uznawane za szczególną 
uciążliwość. Mieszkańcy zatem wybierają, z dostępnej dla nich w okolicy oferty, te funkcje i te lokalizacje, które odpowiadają im najbardziej i konstruują swą własną, mentalną mapę środowiska, z którym się identyfikują. Miasta, bazujące na nowej skali czasu to w pojęciu każdego mieszkańca zestaw obejmujący: miejsce zamieszkania, miejsce pracy, jedno duże centrum usługowe, pomniejsze skupiska sklepów zlokalizowane wzdłuż drogi i jedno tradycyjne centrum starego typu. Zestaw taki nie jest stały - zawsze pojechać można gdzie indziej jeżeli wybrany punkt docelowy znajduje się w możliwej do zaakceptowania 'odległości czasowej' [7].

Dlatego tak istotne jest zachowanie sieci centrów „starego typu” - osiedlowych, które będąc miejscami węzłowymi zatrzymywałyby część mieszkańców dając im wysokiej jakości podstawowe usługi, do których należy również rekreacja. Jest oczywiste, że miejsca węzłowe w obszarach mieszkaniowych czy osiedlach stanowią w mieście tę najdrobniejszą formację sieci ale niezwykle ważną, bo najbliższą człowiekowi.

Przykładów intensyfikowania węzłów istniejących i tworzenia nowych dostarczają zarówno Kraków - rozwijanie węzłów projektowanych w osiedlach z lat 70. a często wtedy niedoinwestowanych, jak np. w zespole osiedli Mistrzejowice w Krakowie, czy miasta austriackie z osiedlami - Solar City w Linzu, Kabelwerk i Nordbahnhof Area w Wiedniu.
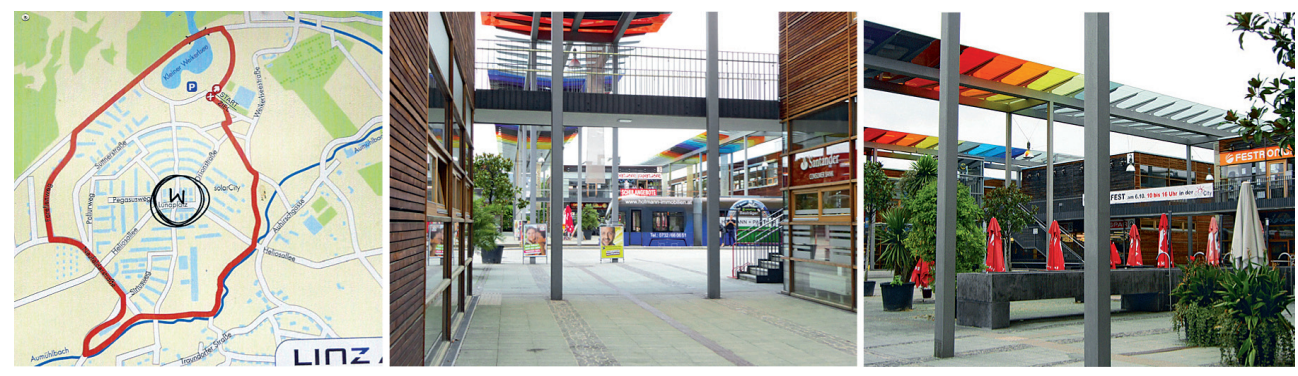

Il. 9, 10, 11. Koncepcja zrealizowanej jednostki Solar City w Linzu jest współczesną wersją osiedla z wyraźnie wyróżniającym się miejscem węzłowym umieszczonym w punkcie przecięcia się wszystkich ciągów komunikacyjnych. Miejsce jest skupiskiem usług, a nadano mu charakterystyczny, zapamiętywalny wyraz estetyczny. (fot. Autorka)

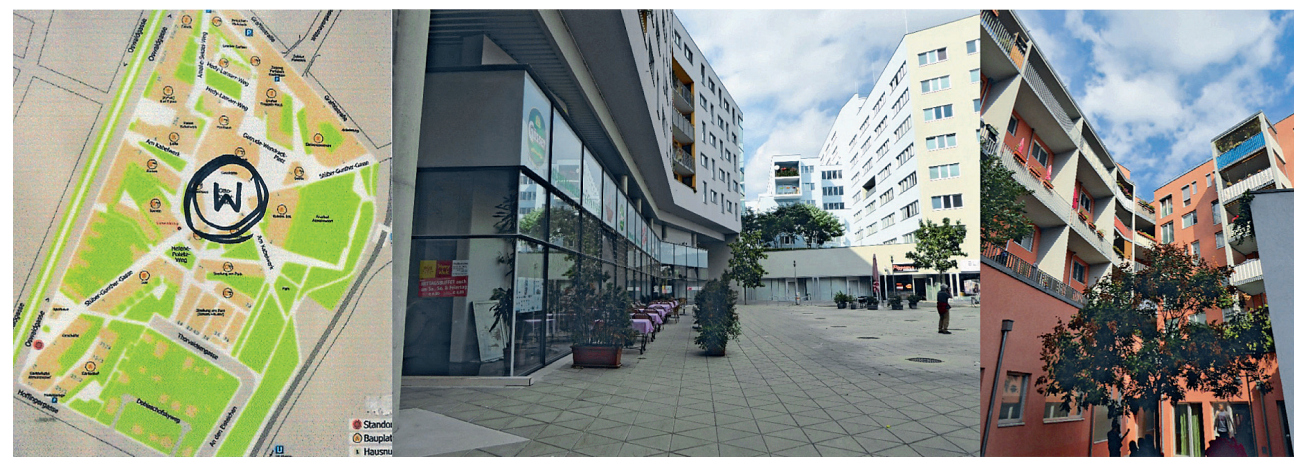

Il. $12,13,14$. W zespole mieszkaniowym Kabelwerk powstałym na rewitalizowanym, poprzemysłowym terenie wyznaczono miejsce węzłowe, skupiające i pozwalające na identyfikację z miejscem. Sprzyja temu charakterystyczna forma urbanistyczna i estetyka architektury 


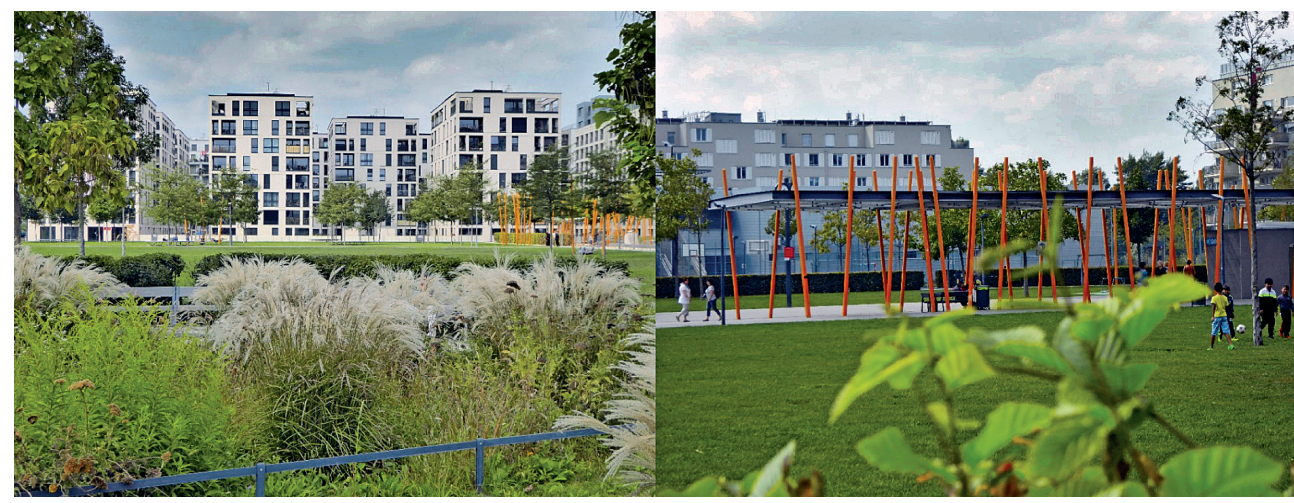

Il. 15, 16. Atrakcyjny park w Nordbahnhof Area będąc elementem obszarowym może być traktowany jak miejsce węzłowe w rozumieniu miejsca węzłowego w strukturach mieszkaniowych, może być wyznacznikiem czytelności struktury nie tylko osiedla ale większego obszaru

\section{Literatura}

[1] Polska polityka architektoniczna Polityka jakości krajobrazu, przestrzeni publicznej, architektury. wyd. Polska Rada Architektury, Sarp, Tup, Izba Architektów Rp Akapit-DTP, 2011.

[2] Przestrzeń życia Polaków - diagnoza i rekomendacje. Fundacja PZU, SARP, Architektura-murator, ZPR Media SA, 2014.

[3] Wejchert K. Elementy kompozycji urbanistycznej, Arkady, Warszawa, 1974.

[4] Lynch K. Obraz miasta. Archivolta, 2011.

[5] Diagnoza funkcjonalno-przestrzenna osiedli: Olsza II, Ugorek. red. J. Kobylarczyk, G. Schneider-Skalska, P. Haupt, K. Racoń-Leja; Wyd. Politechniki Krakowskiej, Kraków, 2015.

[6] Osiedle Ruczaj - Diagnoza obszaru mieszkaniowego. Opracowanie wykonane pod kierunkiem L. Jasińskiego, P. Haupt w ramach Studiów Podyplomowych „Środowisko mieszkaniowe w obszarach zurbanizowanych", Instytutu Projektowania Urbanistycznego, WA PK we współpracy z UM Krakowa; (kierownik Studium. G. Schneider-Skalska), 2016, w zbiorach IPU WA PK.

[7] Palej A. Miasto jako miejsce do życia w epoce informacyjnej [w:] Obszary mieszkaniowe w strukturze miasta. Praca zbiorowa pod. red. G. Schneider-Skalskiej, E. Kusińskiej, Wyd. Politechniki Krakowskiej, 2017.

[8] Dobroczyński B. Wyjść z siebie, wrócić lepszym. Rezczpospolita - PlusMinus, 8-9 lipca 2017.

[9] Fala za fala. rozmowa z Alvinem Tofflerem, „Gazeta Wyborcza”, 24 grudnia 1998.

[10] Jakość i standardy przestrzeni zamieszkania. rozdział pod. kier. A. Noworola [w:] Przestrzeń życia Polaków - diagnoza i rekomendacje, Fundacja PZU, SARP, Architektura-murator, ZPR Media SA, 2014.

[11] Czyżewska E., Czyżewski A. Jakość polskiej przestrzeni publicznej [w:] Przestrzeń życia Polaków - diagnoza i rekomendacje. Fundacja PZU, SARP, Architektura-murator, ZPR Media SA, 2014.

[12] Rogers R., Power A. Cities for a small country. faber\&faber, Bambridge, 2000.

[13] Modelowe rozwiąania struktur osiedlowych w zakresie formy zabudowy oraz struktury ustugowej i społecznej. W. Cęckiewicz z zespołem; Program Rządowy PR-5, Kompleksowy rozwój budownictwa mieszkaniowego.” Temat 2.2. Instytut Urbanistyki i Planowania Przestrzennego Politechniki Krakowskiej, Kraków 1977; zbiory IPU. 


\title{
Node as elements crystallizing residential areas created in the $X X$ and $X X I$ century
}

\author{
Grażyna Schneider-Skalska
}

\author{
Chair of Housing Environment, Faculty of Architecture, Cracow University of Technology, \\ e-mail:gsskalska@.interia.pl; gschneid@pk.edu.pl
}

\begin{abstract}
The increase in the number of urban inhabitants means the increase in the number of dwellings, the enlargement of areas occupied by housing complexes, the visible phenomenon of spatial chaos, the lack of urban composition, forms and places crystallizing space. Diagnosis developed for the housing environment shows such features of newly created housing spaces as lack of continuity of communication systems, ineffective linkages of the land or ineffective localization of public services and green areas. Residential areas in the structure of the city dominate both in terms of occupied areas and the size of built structure. Hence their location should not be accidental, and their service program should not be residual and chaotic. Nodal areas as one of the crystallizing elements of the city space seem to be particularly desirable in the new residential areas created after 1989. The problem seems to be wider, as the study also indicates the lack of crystallization sites in the large multi-family housing estates of the 1960s and 1970s. Thinking about the system of nodal points leads directly to the return to models in urban planning. Nodes forming a network are functional-spatial determinants that can help in the continuation and reconstruction of the urban structure in areas that are not developing smoothly. They can set the scale and place in the hierarchy, introduce distinctive architectural expression leaving much freedom in shaping space between nodes.
\end{abstract}

Keywords: housing areas, nodes, urban models. 